\title{
SHEAR STRENGTHENING OF REINFORCED CONCRETE BEAMS USING EPOXY BONDED STEEL PLATES, CFRP SHEETS AND EXTERNALLY ANCHORED STIRRUPS
}

\author{
Ha Minh ${ }^{1}$ and Hiroshi Mutsuyoshi ${ }^{2}$ \\ ${ }^{1}$ Consultant and Inspection Joint Stock Company of \\ Construction Technology and Equipment - CONINCO \\ ${ }^{2}$ Saitama University, Japan
}

\begin{abstract}
This research presents the effectiveness of different shear strengthening methods using epoxy bonded steel plates, steel strips, carbon fiber reinforced plastics (CFRP) sheets and externally anchored stirrups for enhancing the shear strength of RC beams. In this study, an experimental program including two series of twelve specimens was carried out to investigate the behavior of RC beams strengthened with the above methods. Further, a numerical analysis using finite element method (FEM) was performed to simulate the behavior of strengthened beams. The effectiveness of using epoxy bonded steel plates, CFRP sheets and externally anchored stirrups for shear strengthening of RC beams is confirmed through both numerical and experimental results.
\end{abstract}

\section{INTRODUCTION}

Rehabilitation of existing concrete structures is now one of the major activities of the construction industry. Concrete structures deteriorate due to many reasons such as corrosion of internal reinforcement, carbonation, chloride attack, freeze-thaw action, etc. A number of civil infrastructures are in state of serious deterioration around the world. Further, poor initial design and construction faults also render existing concrete structure deficient. However, the other important reason for strengthening concrete structures is due to continuous upgrading of design codes and increased live load, as the requirements demanded of infrastructures grow with the development of the society. In Japan, for example, the design vehicle load for highway bridges has recently been increased from $196 \mathrm{kN}$ to 245 $\mathrm{kN}$. There is a fear that there are still many existing bridge girders designed with actual shear strength being significantly less than the required shear capacity. These structures must be either replaced or strengthened so that they continue to provide services without risk to human life and property. It is becoming both environmentally and economically preferable to upgrade such deficient structures rather than rebuilding them. Therefore, in order to maintain efficient highway networks and to keep the bridges operational and safe, strengthening and retrofitting of existing concrete structures is desirable if speedy, reliable, economic and simple strengthening techniques are established. Though the RC 
beams are generally over-designed against shear type of failure, there are many cases when $\mathrm{RC}$ beams have been found to be deficient in shear. Therefore, shear strengthening of RC beams becomes necessary and should be considered seriously.

The objective of this paper is to present the effectiveness of different methods using epoxy bonded steel plates, steel strips, CFRP sheets and externally anchored stirrups for shear strengthening RC beams. In this study, an experimental program including two series of twelve specimens was carried out at Structural Material Laboratory of Saitama University, Japan to investigate the shear behavior and shear strengthening characteristic of RC beams strengthened with the above methods. The experiment series-A was carried out to investigate whether a brittle shear failure can be changed to a ductile flexural one by enhancing shear capacity of RC beams. The experiment series-B was conducted to assess the actual shear strength increment of RC beams strengthened with such different techniques. Further, a numerical analysis using finite element method was performed to simulate the behavior of strengthened beams. Two sets of analysis were conducted; the first one assuming the perfect bond between concrete and strengthened steel plates/CFRP sheets and the second set using the adhesive interface element, considering the slip and debonding between steel plates/CFRP sheets and concrete. The effectiveness of using epoxy bonded steel plates, CFRP sheets and externally anchored stirrups for shear strengthening of RC beams is confirmed through both numerical and experimental results.

\section{EXPERIMENTAL INVESTIGATION}

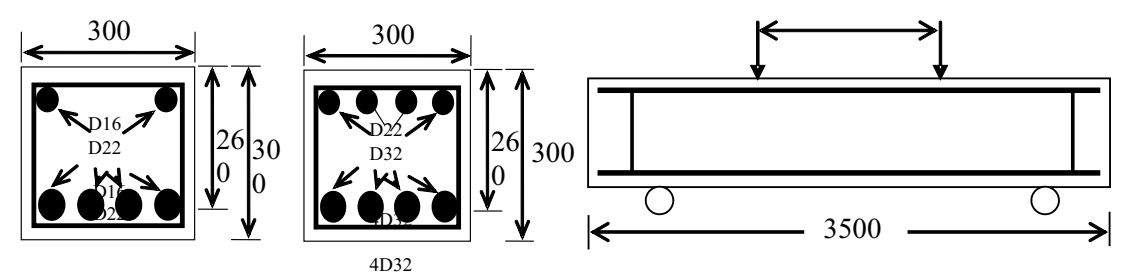

a) Beam series-A

b) Beam series-B

Fig. 1. Details of test beam series-A and series-B (mm)

Total twelve specimens consisting of series-A (Fig.1.a) and series-B (Fig.1.b) were tested in this study. The cross section of all beams was $300 \mathrm{~mm}$ x $300 \mathrm{~mm}$ and the length of the beams was $3500 \mathrm{~mm}$, as shown in Fig.1. No internal stirrups were provided in the desired shear failure region. The beam series-A was designed to have shear to flexural strength ratio of 0.68 , since the purpose was to devise such strengthening techniques so that the structure ultimately fails in flexure. Beam A-1 was kept as the control beam. Steel brackets were installed in beam A-2 to simulate the actual field structure, in RC rigid frames used in some elevated highways in Japan. The purpose of steel brackets in actual field structure is to provide additional support to the longitudinal steel girders in the event of large earthquakes. Beams A-3-1 and A-3-2 were strengthened with steel plates bonded on shear spans. In beam A-3-2, three M12 anchors bolts were used for additional anchorage to steel plates. In beam A-4, $12 \mathrm{~mm}$ diameter round bars were anchored at top and bottom 
using steel angles (L-50x50x8) so as to act as external stirrups. Beam A-5 was bonded with vertical steel strips with additional anchorage at top and bottom. The beam series-B was designed to have shear to flexural strength ratio of 0.42 . All beams in series-B were designed to fail in shear even after strengthening with different techniques, since the purpose was to assess the actual shear strength increment. Beam B-1 was kept as a control beam. The steel brackets were installed in beam B-2. Beams B-3-1 and B-3-2 were strengthened with steel plates bonded on shear spans without and with anchors respectively. Beam B-4 was strengthened with external stirrups. Beam B-5 was strengthened with U-wrappedepoxy-bonded-single-layer CFRP sheets on shear spans. The different shear strengthening methods used in the experiments are shown in Fig.2.
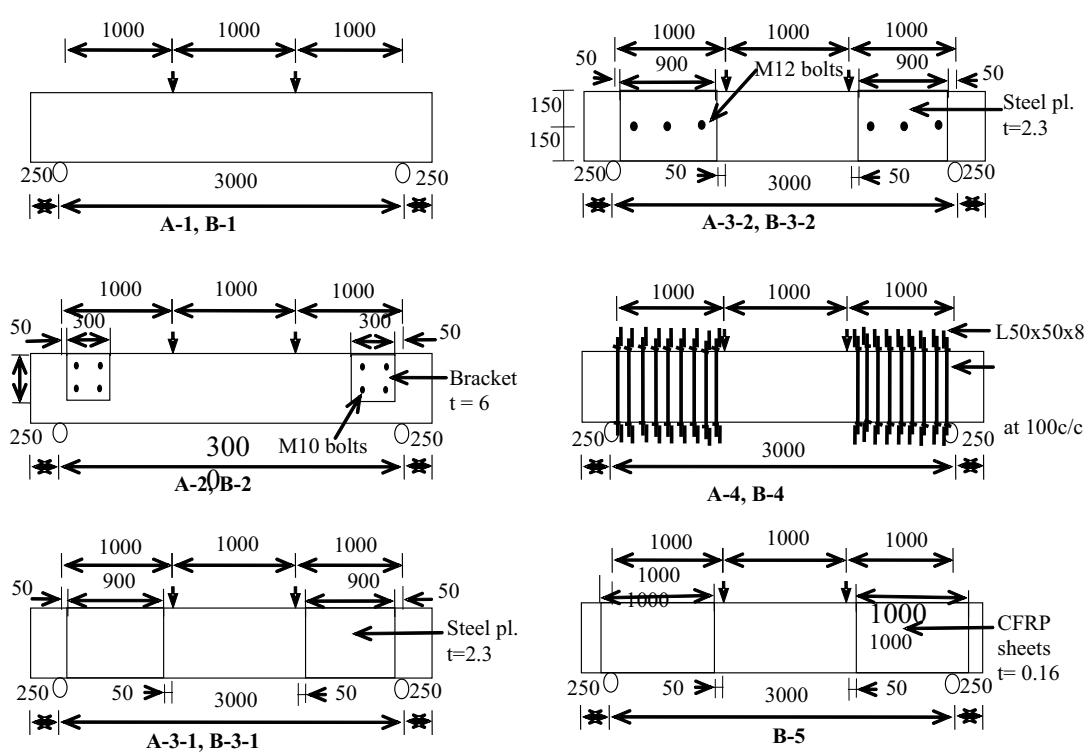

Fig. 2. Different shear strengthening methods

The average compressive strength of concrete used in the experiment was $36 \mathrm{MPa}$. Table 1 shows the mechanical properties of reinforcements, steel plates, round bars and CFRP sheets used in the experiment.

All of the beams were tested under four-point loading over the span of $3000 \mathrm{~mm}$. The shear span to effective depth ratio was 3.85 in all tests. Load was applied monotonically to the test beams until failure. Strains, deflection and the applied load were recorded at every load increment. Crack initiation and propagation were monitored by visual inspection during testing.

\section{RESULTS OF EXPERIMENTS AND DISCUSSIONS}

The control beam A-1 failed in shear due to a critical diagonal crack in one of the shear spans. Beam A-2 with steel bracket also failed in shear but at a little higher load. It means that the effect of bracket was very little, since most of the location of the bracket was out of the critical shear failure zone. Beam A-3-1 and A-3-2 with epoxy bonded steel 
Table 1. Mechanical properties of reinforcements, steel plates, round bars and CFRP sheets used in the experiment

\begin{tabular}{|l|l|l|l|}
\hline $\begin{array}{l}\text { Reinforcements, } \\
\text { Steel plates, CFRP sheets }\end{array}$ & $\begin{array}{l}\text { Yield strength } \\
(\mathrm{MPa})\end{array}$ & $\begin{array}{l}\text { Ultimate strength } \\
(\mathrm{MPa})\end{array}$ & $\begin{array}{l}\text { Elastic modulus } \\
(\mathrm{GPa})\end{array}$ \\
\hline D6 & 346 & 544 & 192 \\
\hline D13 & 386 & 577 & 175 \\
\hline D22 & 391 & 581 & 182 \\
\hline D32 & 398 & 595 & 206 \\
\hline Steel plate $(\mathrm{t}=2.3 \mathrm{~mm})$ & 306 & 394 & 199 \\
\hline Steel plate $(\mathrm{t}=4.5 \mathrm{~mm})$ & 345 & 420 & 207 \\
\hline Steel plate $\mathrm{t}=6.0 \mathrm{~mm})$ & 347 & 463 & 196 \\
\hline $10 \mathrm{~mm}$ diameter round bar & 450 & - & 206 \\
\hline 12 mm diameter round bar & 480 & - & 210 \\
\hline CFRP sheet $(\mathrm{t}=0.16 \mathrm{~mm})$ & - & 3400 & 230 \\
\hline
\end{tabular}

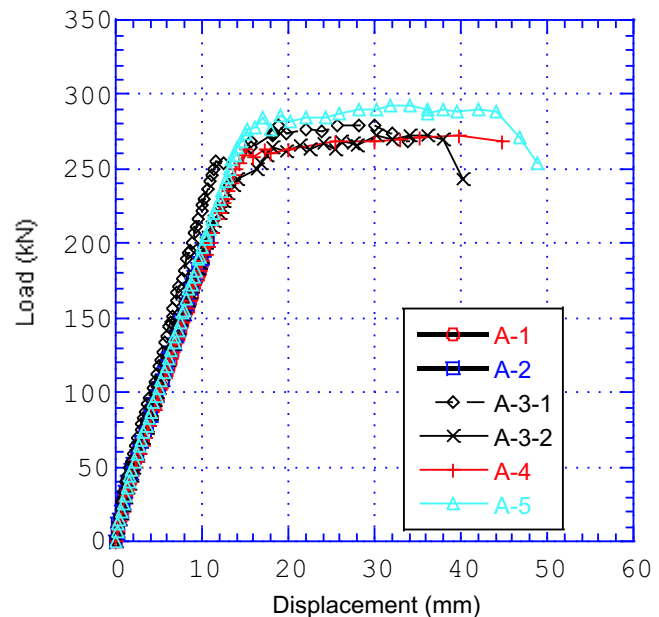

Fig. 3. Load-displacement curves (Series-A)

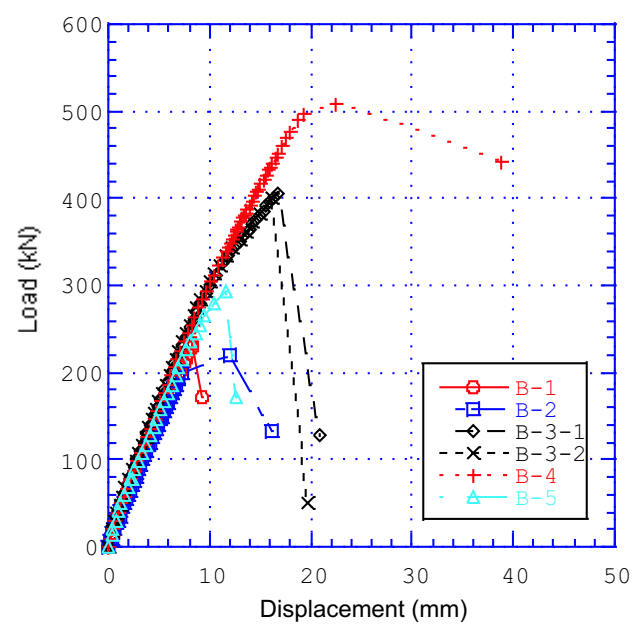

Fig. 4. Load-displacement curves (Series-B)

plates failed in flexural mode at almost the same load level because the arrangement of steel plates did not enhance their ultimate flexural strengths. The increase in ultimate failure load was approximately $49 \%$ and $46 \%$ for beam A-3-1 and A-3-2 respectively compared with beam A-1. Beam A-4 and A-5 also failed in flexural mode with re-bar yielding followed by concrete crushing. With the reference to the control beam A-1, the increase in ultimate failure load was $46 \%$ and $56 \%$ for beam A-4 and A-5 respectively. The results confirmed the effectiveness of devised strengthening methods for shear enhancement of these beams. Since all strengthened beams in series-A failed in flexural mode, the actual ultimate shear strength increment could not be estimated. In beam series-B, the control beam B-1 and beam B-2 with steel brackets failed in shear at almost the same load level, it is confirmed that steel brackets has almost no effect in shear strengthening. Beams B-3-1 and B-3-2 also 
failed in shear at almost the same load level. It shows that there is no effect of additional anchors provided on beam B-3-2, since in both cases failures were almost identical and the tensile strains developed in anchor bolts were almost negligible. The shear strength increment was approximately $72 \%$ for these beams compared with beam B-1. Beam B-4 failed in flexure and crushing of concrete occurred finally in the compression zone. This implies a higher or at least the same shear capacity of the beam B-4 as the observed flexural failure load. With reference to the beam B-1, the increase in ultimate shear strength was at least $117 \%$ for this beam. Beam B-5 failed in shear and debonding of CFRP sheets from concrete surface was observed. The increase in shear strength was approximately $26 \%$ for beam B-5. Fig.3 and Fig.4 show the comparative load versus mid-span displacement relationships for all beams in series-A and series-B. The experimental result for all beams is shown in Table 2.

\section{FINITE ELEMENT SIMULATION}
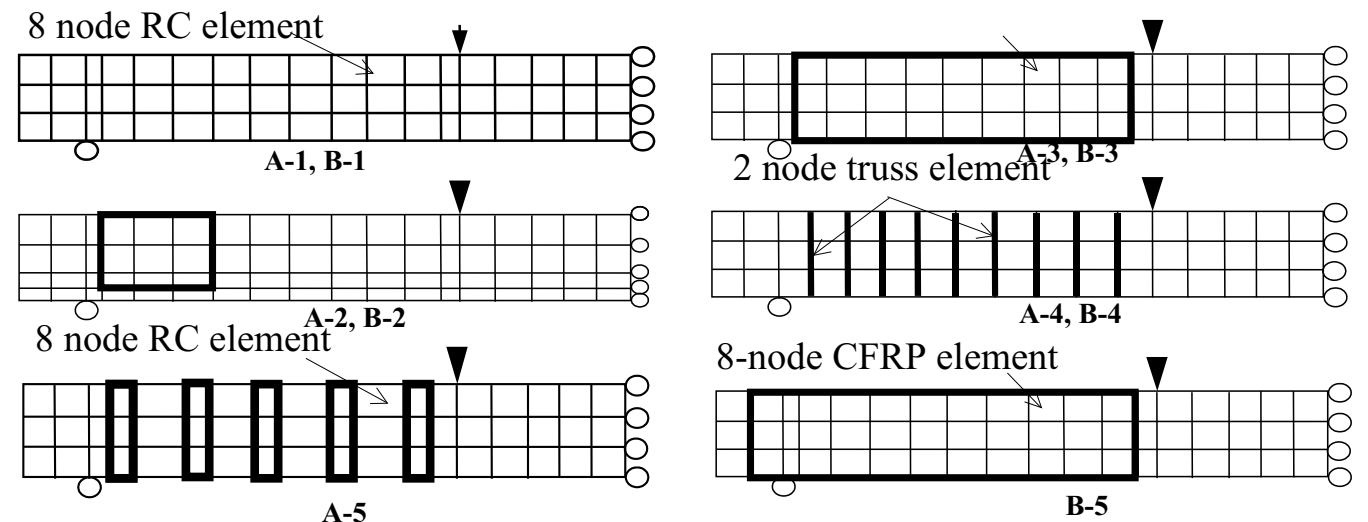

Fig. 5. Finite element meshes for all beams

To simulate the behavior of beams strengthened with epoxy bonded steel plates and CFRP sheets, a nonlinear finite element method was adopted. Due to the symmetry of geometry of the beams and loading pattern, only a half span of each beam was analyzed assuming appropriate boundary conditions along the line of symmetry. The reinforced concrete, steel plate and CFRP sheet elements were modeled using eight-node plane-stress elements. Steel plate and CFRP elements were superimposed on RC elements in the first set of analysis, whereas 16-node interface elements were used in the second set of analysis. Two-node truss elements were used for external stirrups. Finite element meshes for all beams are shown in Fig.5. Table 2 shows the comparison of the results between the test and the FEM analysis for all the tested beams.

Numerical failure modes, ultimate failure loads, and the load-displacement relationships obtained from the analysis were compared with the experimental results. In beam series-A, the ultimate failure loads obtained from FEM analysis were well within 10\% range of test values. The results from both sets of analyses were similar. This might be 
due to occurrence of flexural failures of strengthened beams before reaching the shear capacity. In beam series-B, it is seen that the perfect bond analysis gave erroneous results in terms of both failure modes and failure loads in beams strengthened with steel plates and CFRP sheets, whereas the analysis with interface element predicted the failure loads as well as failure modes of those beams quite well. It is confirmed that the assumption of perfect bond between steel plates/CFRP sheets and concrete cannot be used in general case for strengthened beams. Fig.6, Fig.7 and Fig. 8 show the load versus displacement relationships for some selected beams from experiment and analysis. These figures show good agreement between experimental and numerical curves.

Table 2. Results from experiment and analysis for all beams

Analysis 1: Perfect bond; Analysis 2: Interface element

\begin{tabular}{|l|c|c|c|c|c|}
\hline $\begin{array}{l}\text { Beam } \\
\text { No. }\end{array}$ & $\begin{array}{c}\text { Failure load (kN)/ } \\
\text { mode (Exp.) }\end{array}$ & $\begin{array}{c}\text { Failure load (kN)/ } \\
\text { mode (Ana. (1)) }\end{array}$ & $\begin{array}{c}\text { Failure load (kN)/ } \\
\text { mode (Ana. (2)) }\end{array}$ & $\begin{array}{c}\text { Ana.(1)/ } \\
\text { Exp. }\end{array}$ & $\begin{array}{c}\text { Ana. (2)/ } \\
\text { Exp. }\end{array}$ \\
\hline A-1 & $187.0 /$ shear & $190.1 /$ shear & $190.1 /$ shear & 1.02 & 1.02 \\
\hline A-2 & $201.0 /$ shear & $199.9 /$ shear & $199.9 /$ shear & 0.99 & 0.99 \\
\hline A-3-1 & $279.3 /$ flexure & $297.9 /$ flexure & $295.9 /$ flexure & 1.07 & 1.06 \\
\hline A-3-2 & $272.2 /$ flexure & $297.9 /$ flexure & $295.9 /$ flexure & 1.09 & 1.08 \\
\hline A-4 & $272.5 /$ flexure & $290.0 /$ flexure & $290.0 /$ flexure & 1.06 & 1.06 \\
\hline A-5 & $292.0 /$ flexure & $298.0 /$ flexure & $298.0 /$ flexure & 1.02 & 1.02 \\
\hline B-1 & $233.6 /$ shear & $234.6 /$ shear & $234.6 /$ shear & 1.00 & 1.00 \\
\hline B-2 & $220.5 /$ shear & $263.2 /$ shear & $263.2 /$ shear & 1.19 & 1.19 \\
\hline B-3-1 & $405.5 /$ shear & $568.1 /$ flexure & $416.9 /$ shear & 1.40 & 1.03 \\
\hline B-3-2 & $400.6 /$ shear & $568.1 /$ flexure & $416.9 /$ shear & 1.42 & 1.04 \\
\hline B-4 & $507.6 /$ flexure & $483.5 /$ shear & $483.5 /$ shear & 0.95 & 0.95 \\
\hline B-5 & $293.2 /$ shear & $470.0 /$ shear & $341.0 /$ shear & 1.60 & 1.16 \\
\hline
\end{tabular}

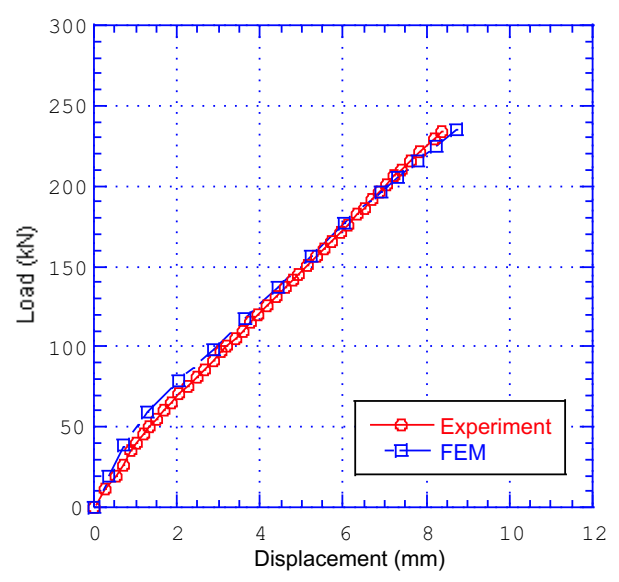

Fig. 6. Load-displacement relationship (B-1)

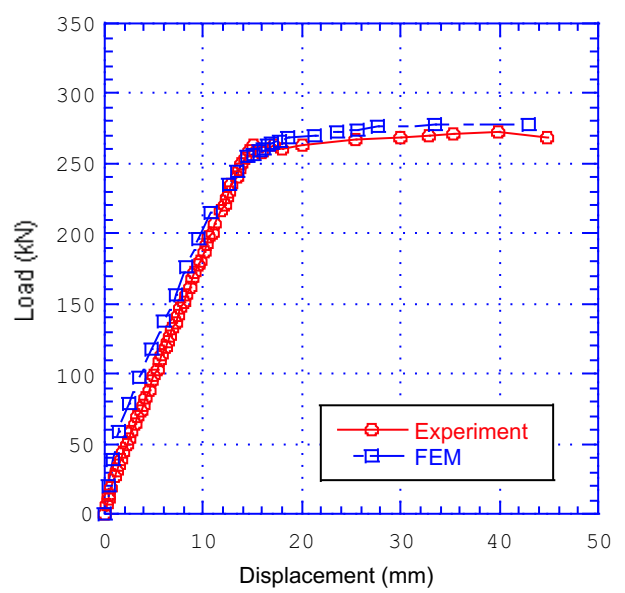

Fig. \%. Load-displacement relationship (A-4) 


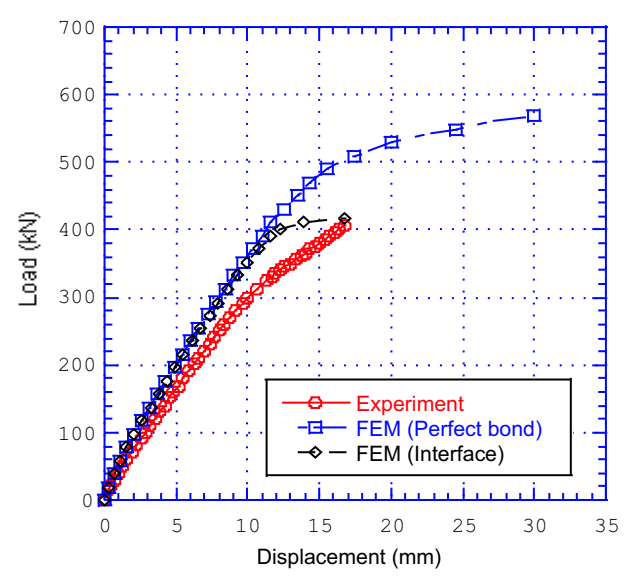

Fig. 8. Load-displacement relationship (B-3-2)

\section{CONCLUSIONS}

Experimental and numerical studies are performed for shear with epoxy bonded steel plates, steel strips, CFRP sheets and externally anchored stirrups. All the strengthening schemes are found to be effective for shear strengthening of RC beams. From the results of this research, the following conclusions can be drawn.

1) It is confirmed that the epoxy bonded steel plates, steel strips, CFRP sheets and externally anchored stirrups can improve the ultimate shear strength of RC beams.

2) From the results of experiments, an average $72 \%$ increase in shear strength was obtained for the beam with steel plates and at least $117 \%$ shear strength increment was gained for beam with external stirrups. These methods can be used effectively for shear strengthening of RC beams. However, only $26 \%$ increase in shear strength was obtained for the beam with U-wrapped-epoxy-bonded CFRP sheets, which might be due to the debonding of CFRP sheets from concrete surface.

3) The steel bracket has almost no effect for shear strengthening of RC beams because most of bracket location was out of the critical shear failure zone.

4) All the strengthening methods studied did not enhance the flexural strength of the beams; however, marginal increases in the flexural stiffness were observed in the beams with steel plates.

5) In shear strengthening technique using steel plates bonded on shear spans, if the bonding layer between steel plates and concrete surface is well prepared, the additional anchors have almost no effect. However, these anchors are essential for the safety in case of natural hazards such as fires, where epoxy adhesive loses its strength. These are also necessary for placing and aligning the steel plates during the bonding operation. If large number of anchors is used, the effect can be substantial.

6) The FEM analysis presented in this study was an effective method to predict the ultimate shear strength quite satisfactorily as well as the overall behavior of the RC beams strengthened with different techniques within an acceptable accuracy. 
For beam series-A, since the failures of strengthened beams were due to flexure, both sets of analysis with perfect bond assumption and with interface element showed almost similar results. Therefore, the assumption of perfect bond was found to be satisfactory owing to little influence of slip and local debonding.

For beam series-B, the perfect bond analysis gave erroneous results in terms of both failure modes and failure loads, since most of strengthened beams failed in shear and local debonding of steel plates/CFRP sheets occurred. However, the new analysis predicted the failure loads as well as the overall behavior quite well and showed good agreements with experimental results. It is confirmed that the assumption of perfect bond between steel plates/CFRP sheets cannot be used in general case for strengthened beams.

\section{REFERENCES}

[1] H. Minh, H. Mutsuyoshi, B. B. Adhikary and K. Watanabe, Experimental and FEM Study for Shear, Strengthening of Reinforced Concrete Beams Using Different Techniques, Transactions of The Japan Concrete Institute, Vol. 23, 2001, pp. 365-370.

[2] H. Minh, H. Mutsuyoshi, B. B. and Adhikary, Shear Strengthening of Reinforced Concrete Beams Using Epoxy Bonded Steel Plates, Proceedings of International Conference on Advanced Technologies in Design, Construction and Maintenance of Concrete Structures, ICCMC, Hanoi, Vietnam, 2001, pp. 269-275.

[3] H. Okamura, and K. Maekawa, Nonlinear Analysis and Constitutive Models of Reinforced Concrete, Gihodo Press, Tokyo, 1991, pp. 1-182

[4] A. Shawky, and K. Maekawa, Nonlinear Response of Underground RC Structures under Shear, Journal of Materials Concrete Structures and Pavements 31 (538) (1996) 195-206, JSCE.

[5] T. C. Triantafillou, Shear Strengthening of Reinforced Concrete Beams using Epoxy-Bonded FRP Composites, ACI Structural Journal 95 (2) (1998) 107-115.

[6] A. Xuehui, K. Maekawa, and H. Okamura, Numerical Simulation of Size Effect in Shear Strength of RC beams, Journal of Materials Concrete Structures and Pavements 35 (564) 297-316.

Received April 30, 2009

\section{Độ BỀN TRƯợT CỦA DẦM BÊ TÔNG CỐT THÉP SỬ DƯNG THÉP TÂM DÁN BẰNG EPOXY, TẤM CFRP VÀ NEO BẰNG NẸP NGOÀI}

Nghiên cứu này trình bày hiệu quả của các phương pháp gia tăng độ cứng chống trượt khác nhau sử dụng thép tấm dán bằng epoxy, các dải thép và các tấm nhựa gia cường bằng sợi carbon (CFRP) và neo bằng các nẹp ngoài để tạo ra độ bền chống trượt cho dầm bê tông cốt thép. Trong công trình này đã tiến hành chương trình thí nghiệm cho hai loạt mẫu với 12 mẫu thí nghiệm để nghiên cứu ứng xử của dầm bê tông cốt thép gia cường bằng các phương pháp kể trên. Sau đó, tiến hành phân tích số sử dụng phương pháp phần tử hữu hạn để mô phỏng ứng xử của dầm được gia cường. Hiệu quả của việc dùng thép tấm được dán bằng epoxy, tấm CFRP và nẹp ngoài để gia tăng độ bền chống trượt của dầm bê tông cốt thép được đánh giá bằng cả kết quả số và thực nghiệm. 